\title{
The Effect of Using Specific Strength Trainings-Based Educational Therapy Style on the Treatment of Learning Girls in Front Crawl
}

\section{"Dr. Riham Ahmed Fadel Abdul-Aziz}

\section{Abstract}

This research aims at identifying learning disabilities and sources of mistakes in front crawl for students with learning disabilities, in addition to recognizing the efficiency of specific strength trainings-based educational therapy on the level of technical performance in front crawl for students with learning disabilities. The researcher has conducted an empirical study on a sample of (40) second-year undergraduate students with learning disabilities at the Faculty of Physical Education for Girls, Zagazig University. They were divided into two groups; an experimental group and a control group of (20) students each. The research tools included: imagery intelligence test - evaluation of the technical performance of front crawl - an educational program based on specific strength trainingsbased educational therapy.

Key results:

1- The effectiveness of specific strength trainingsbased educational therapy style in the promotion of the level of technical performance of front crawl for students with learning disabilities.

Key recommendations:

1- The necessity of using specific strength trainingsbased educational therapy for mastering front crawl for students with learning disabilities.

2- The necessity of using specific strength trainings under consideration while teaching and training students at the Faculty of Physical Education in front crawl.

Introduction and problematic Educational therapy style is a kind of teaching which focuses on a specific learning disability and pays special attention to it after identifying its degree of difficulty by means of assessment. When some learners don't pass the formative assessment, a working plan is being introduced in order to

Lecture at the Department of Water Sports and Fencing Faculty of Physical Education for Girls - Zagazig University 
strengthen their weaknesses. In this research, the researcher defines learning disability as the students' failure to understand and master front crawl.

At recent days, new trends of a certain kind of trainings called specific strength trainings or purposeful exercises have emerged. Such trainings help in promoting the level of many skills performance in different sports activities. This kind of trainings is highly specialized in developing the quantity, quality and timing of skills performance in accordance with the instantaneous use of muscles or muscle groupswithinthe physical performance of skillsfor those who practice this kind of sports activity.

Issam Abdel-Khalek (2003) indicates that specific strength trainings are sports movements whose formation is similar, in terms of the performance of skills such as strength, time path of strength and direction of muscle action, to the performed movements. So, it's considered as a direct means for the principal preparation for sports level in order to develop the subject's training condition; so the subject's movement becomes suitable for the type of its specialized sports activity in terms of motor co-ordination and sequencing of the pathway and direction of motor performance. These trainings should be taken into consideration during preparation and competitions. The function of specific strength trainings is to help in mastering the motor performance of the practiced activity and to apply it in different forms by developing specific skill components for the practiced activity in order to develop it rapidly.

Learning disabilities are disorders in the ability to learn effectively in a way that does not correspond to the individual's real abilities. This appears in the form of disorders in the learner's ability to receive, organize or express information related to academic performance. This can also appear through a remarkable disparity between the individual's ability in general and his performance in the same time.

The risk of learning disabilities problem consists in the fact that they are "invisible 
disabilities". Learners with learning disabilities are usually healthy people. The teacher and the family don't notice any strange signs that may require special treatment. So the teachers find nothing to do except calling them lazy, careless or stupid. The normal consequence of such practices is repeated failures and, consequently, school dropouts.

Swimming sport is the essential foundation for practicing water sports. It's one of the individual sports that require, in order to be mastered, a clear perception of the form of the swimming stroke by using some instructional techniques so that the student could watch the exact details of front crawl (body position - leg kicks arm movement - breathing co-ordination). There is a principal problem that many of those who learn to swim face: transmitting experience to others seen that the process itself of teaching how to swimrequirescorrect and gradual steps. Many cases of failure to learn how to swimaredue to some false ideas in the learning process.

Through the researcher's experience in teaching swimming curriculum for the first-year undergraduate students at the Faculty of Physical Education for Girls,ZagazigUniversity, and her participation in the faculty's practical exams, she has noticed that some learners' level of frontcrawl improves while others; level reduces in spite of experiencing the same educational conditions. She has also found that a big number of students could not perform front crawl successfully during the practical exams, which draw the researcher's attention. This indicates that the learning process encounters some difficulties that hinder its progress. This may be due to the use of command teaching style which depends on verbal explanations and model of practical skill without any active participation from the students in the educational situation. Or maybe it's the negligence of individual differences and the ignorance of the learner's subjectivity which leads to disabilities in the learning process. Furthermore, the non use of specific strength trainings in leaning front crawl interferes with modern teaching trendswhichcall to paying 
attention to the learner and the necessity of teaching him in accordance with his own abilities, potentialities and rhythm of learning in order to make of him an active element in the educational process.

The above drove the researcher to use educational therapy style as a modern and broad style through which learning disabilities in front crawl could be treated among second-year undergraduate students at the Faculty of Physical Education for Girls, Zagazig University.

The importance of this research consists in the fact that it constitutes an attempt to identify learning disabilities in front crawl among students and to try to get over such difficulties by using specific strength trainings-based educational therapy.

\section{Research aims :}

\section{This research aims at:}

1- Identifying the effect of using specific strength trainings-based educational therapy on the level of technical performance in front crawl among students with learning disabilities.

2- $\quad$ Identifying the effect of using command teaching style on the level of technical performance in front crawl among students with learning disabilities.

3- Identifying the differences between using specific strength trainingsbased educational therapy and command teaching style on the level of technical performance in front crawl among students with learning disabilities.

\section{Research hypotheses:}

1- There are statistically significant differences between the averages of pre and post tests of the control group in terms of the technical performance in front crawl among students with learning disabilities in favor of post tests.

2- There are statistically significant differences between the averages of pre and post tests of the experimental group in terms of the technical performance in front crawl among students with learning disabilities in favor of post tests.

3- There are statistically significant differences between the averages of both post tests of the experimental and the control groups in terms of the technical performance in front crawl among students with learning disabilities in favor of 
the experimental group.

Research procedure:

Methodology:

The researcher has adopted the Experimental method seen that it suits the nature of the research, by designing the pre and post tests of two groups: an experimental and a control group.

\section{Sample and population:}

The researcher has chosen the research subjects among the second-year undergraduate students at the Faculty of Physical Education for Girls, Zagazig University at the second semester of the academic year 2014/2015. They areat the number of (359) students who had already studiedpractical and theoretical swimming curriculum during the first year and the first semester of the second year at the Faculty. The total number of students who failed the practical exam for the first semester of the academic year $2014 / 2015$ in the swimming curriculum is (71) students.

By means of the purposive sampling, the researcher chose a sample from the second-year undergraduate students who had failed the practical exams of the swimming curriculum in the first semester of the academic year 2014/2015. The research's basic sample consisted of (40) students. They were divided into two groups: an experimental group of (20) students who had used the specific strength trainingsbased educational therapy, and a control group of (20) students who had used the traditional method. (15) Students from the research's basic sample had also served as an exploratory sample.

The researcher calculated the normal distribution of the subjects of the research sample in terms of some variances that may affect the experimental variable such as: growth rates (age - height weight - intelligence) and the level of technical performance in front crawl.

Equivalence has also been established between the two groups of the research (the experimental group - the control group) in terms of growth rates under consideration, intelligence and level of technical performance in front crawl as shown in tables (1) and (2).

Table (1) 
Indication of the differences between the experimental and the control groups in terms of growth rates under consideration

\begin{tabular}{l|c|c|c|c|c|c}
\hline \hline \multirow{2}{*}{ Variances } & \multirow{2}{*}{$\begin{array}{c}\text { Unit of } \\
\text { measurement }\end{array}$} & \multicolumn{2}{|c|}{$\begin{array}{c}\text { The experimental } \\
\text { group } \mathbf{N = 2 0}\end{array}$} & \multicolumn{2}{|c|}{$\begin{array}{c}\text { The control group } \\
\mathbf{N = 2 0}\end{array}$} & \multirow{2}{*}{$\begin{array}{c}\text { T } \\
\text { value }\end{array}$} \\
\cline { 3 - 7 } & & independent & dependent & independent & dependent & \\
\hline \hline Age & Years & 19.20 & 0.59 & 19.31 & 0.63 & 0.56 \\
\hline Height & $\mathrm{Cm}$ & 165.41 & 5.11 & 166.00 & 4.98 & 0.36 \\
\hline Weight & $\mathrm{Kg}$ & 66.00 & 5.92 & 67.29 & 5.74 & 0.68 \\
\hline $\begin{array}{l}\text { Imagery } \\
\text { intelligence }\end{array}$ & Grade & 45.20 & 4.76 & 45.70 & 4.62 & 0.33 \\
\hline \hline
\end{tabular}

Value $\mathrm{T}$ is at $0.05=2.042$ significance level

As table (1) shows, there are

no statistically significant differences at level 0.05 between the experimental and the control group in terms of

Table (2)

growth rates (age - height weight -intelligence), which indicates that both groups of the research are equivalent in terms of variables.

Indication of the differences between the experimental and the
control groups in terms of technical performance in front crawl

\begin{tabular}{l|c|c|c|c|c|c}
\hline \multirow{2}{*}{ Variances } & \multirow{2}{*}{$\begin{array}{c}\text { Unit of } \\
\text { measurement }\end{array}$} & \multicolumn{2}{|c|}{$\begin{array}{c}\text { The experimental group } \\
\mathbf{N = 2 0}\end{array}$} & \multicolumn{2}{|c|}{$\begin{array}{c}\text { The control group } \\
\mathbf{N = 2 0}\end{array}$} & \multicolumn{2}{c}{$\begin{array}{c}\text { T } \\
\text { value }\end{array}$} \\
\cline { 3 - 6 } & independent & dependent & independent & dependent & \\
\hline \hline $\begin{array}{l}\text { Front crawl } \\
\text { performance: } \\
\text { Leg kicks }\end{array}$ & Degree & 3.90 & 1.63 & 4.00 & 1.71 & 0.18 \\
\hline $\begin{array}{l}\text { Arm } \\
\text { movement }\end{array}$ & Degree & 2.84 & 1.39 & 2.90 & 1.33 & 0.14 \\
\hline Breathing & Degree & 2.40 & 1.24 & 2.50 & 1.21 & 0.25 \\
\hline $\begin{array}{l}\text { Overall co- } \\
\text { ordination }\end{array}$ & Degree & 2.26 & 1.17 & 2.34 & 1.25 & 0.21 \\
\hline $\begin{array}{l}\text { Level of } \\
\text { front crawl }\end{array}$ & Degree & 11.40 & 3.94 & 11.74 & 4.16 & 0.26 \\
\hline \hline
\end{tabular}

$\mathrm{T}$ value is at $0.05=2.041$ significance level

As table (2) shows, there are no statistically significant differences at level 0.05 between the experimental and the control group in terms of technical performance in front crawl, which indicates that both groups of the research are equivalent in terms of variables.

Data collection tools:

First: equipment and tools used

Assiut Journal For Sport Science Arts 
in the research

- Restameter to measure body's total height

- Calibrated medical weighting scale to measure body weight

- Stopwatch

- $25 \times 12.5$ Pool with tools.

Second: skills testfor the evaluation of the level of performance in front crawl:

A checklist was designed in order to evaluate the level of performance in front crawl as a diagnostic test in order to identify the students' level of technical performance and recognize the latent difficulties in the performance offront crawl. Kamal Abdulhamid and Mohammed Nasr Eddin (2005) indicate that diagnostic assessment is a procedure that implies an attempt to identify the learning disabilities that the learners encounter during the educational process in an attempt to establish a suitable therapeutic educational program.

Accordingly, after having reviewed scientific references onthe teaching of swimming such as Wafeeka Mustafa Salem (2000), Tareq Mohammed Nada (2004), Mustafa Kademet., al (2000), the researcher chose the skills test prepared by Wafeeka Mustafa Salem (2000) for the evaluation of the level of performance of front crawl. The checklist contained specific components such as (legkicks - arm movement breathing - overall coordination). Assessment was conducted through structured observation of the proper performance of basic components. Evaluation was based on the objective selfcriticism of three examiners, by calculatingthe average of their marks, so the checklist's final grade of (40) pointswas distributed on the following basic components:

1- Legkicks (10) points

2- Arm movement points

3- $\quad$ Breathing (10 points

4- Overall co-ordination

(10) points

The researcher indicates that the students' level of technical performance was calculated by three examiners: each examiner gives a specific mark out of (10) to the student on his level of technical performance of front crawlin consideration of (legkicks - arm movement breathing - overall coordination). Afterwards, the 
average of the examiners' three marks was calculated, so the total (40) pointscould define the student's level of performance in front crawl.

Third: the coefficients (validity - reliability) of the level of performance checklist:

The researcher calculated the validity of the checklist of level of performance in front crawl using logical validity by submitting the checklist to (5) swimming specialists in order to have their opinions about how the checklist's content is logical and identical to its purpose. The results have shown the examiners' $(100 \%)$ agreement, which proves the validity of the checklist in question. Also, the reliability coefficient of the form has been calculated by applying the form and then re-applying it on the subjects of the exploratory sample (7) days after its first application. The correlation coefficient between the results of the first and the second application was also calculated and the form's reliability coefficient reached (0.849); which proves that the form is reliable.

Fourth: imagery intelligence test, prepared by/ Ahmed ZakySaleh (1989).
The educational program using specific strength trainingsbased educational therapy:

Objective of the educational program:

1- To improve the level of technical performances in front crawl for students with learning disabilities.

The therapeutic plan of the educational program

The researcher indicates that she has identified learning disabilities in front crawl by applying the level of performance checklist. The researcher was able to identify certain disabilities among the subjects of the experimental group, which disabilities can be summarized as follows:

- Body position (overlifting, over-lowering or overrotating the body).

- $\quad$ Leg kicks (performing scissor leg kicks rather than performing the kicks in a paddling movement, legs cramps, kicking too deep in the water, kicking from the knees, moving the legs too high above water surface)

- Arm movement

(entering into the water from a far point in frontofthe shoulder or from a close point, the elbow gets into the water before the hand, too much 
space between fingers, pulling too deep or close to the body, the hand exitsbeforethe elbow, armcramps)

- Breathing (lifting the head to breathe, failure to exhaleall the air).

- Linking and coordination (weak coordination between leg kicks and arm movement).

Afterwards, the researcher treated these disabilities using a set of specific structured trainings, which trainings were concluded from the study of Riham Ahmed Fadel (2013). The trainings were at the number of (14) including trainings on body position, leg kicks, arm movements, breathing process and overallco-ordination during front crawl. The basic experiment of the research was conducted for (8) continuous weeks, with two modules per week. The total number of modules in the educational program was (16) modules, knowing that the duration of each daily module was (60) minutes distributed as follows:

- Warm-up outside the water $=10$ minutes

- Warm-up inside the water $=5$ minutes
- The principal (educational and practical) part $=40$ minutes.

- The final part $=5$ minutes

- The duration of the module, the module content, material and human capacities were unified between the experimental group which hadused educational therapy style and the control group which had used the traditional method. The only difference between the two groups was the only suggested teaching style.

\section{Pre tests:}

The researcher conducted the pre tests of the subjects of the experimental and the control groups in terms of technical performance in front crawl in the period from 1/3/2015 till 3/3/2015.

Implementation of the educational program using educational therapy style:

The researcher applied the content of the educational program using educational therapy style on the subjects of the experimental group after the end of the day at the faculty, in the period from $5 / 3 / 2015$ till $29 / 4 / 2015$ for a duration of (8) continuous weeks, with two modules per 
week, the duration of each was (60) minutes, while the control group followed the traditional method (command teaching).

Post tests

The post tests of the experimental and the control group were conducted on the technical level of front crawl in the period from $3 / 5 / 2015$ till $5 / 5 / 2015$ following the same order and conditions of pre tests.

Presentation and discussion of results:

Table (3)

Indication of the differences between the pre and post tests of the experimental group in terms of technical performance in front crawl $N=20$

\begin{tabular}{l|l|l|l|l|l|l}
\hline \hline \multirow{2}{*}{ Variances } & \multirow{2}{*}{$\begin{array}{c}\text { Unit of } \\
\text { measurement }\end{array}$} & \multicolumn{2}{|c|}{$\begin{array}{c}\text { The experimental } \\
\text { group N = 20 }\end{array}$} & \multicolumn{2}{c|}{$\begin{array}{r}\text { The control group } \\
\text { N= 20 }\end{array}$} & \multirow{2}{*}{$\begin{array}{c}\text { T } \\
\text { value }\end{array}$} \\
\cline { 3 - 7 } & independent & dependent & independent & dependent & \\
\hline \hline Leg kicks & Degree & 3.90 & 1.63 & 8.78 & 1.14 & $9.37^{*}$ \\
\hline $\begin{array}{l}\text { Arm } \\
\text { movement }\end{array}$ & Degree & 2.84 & 1.39 & 8.40 & 0.97 & $11.52^{*}$ \\
\hline Breathing & Degree & 2.40 & 1.24 & 8.00 & 0.91 & $12.18^{*}$ \\
\hline $\begin{array}{l}\text { Overall } \\
\text { co- } \\
\text { ordination }\end{array}$ & Degree & 2.26 & 1.17 & 7.72 & 0.83 & $12.46^{*}$ \\
\hline $\begin{array}{l}\text { Level of } \\
\text { front } \\
\text { crawl }\end{array}$ & Degree & 11.40 & 3.94 & 32.90 & 2.47 & $18.82^{*}$ \\
\hline \hline
\end{tabular}

$\mathrm{T}$ value is at $0.05=2.093$ significance level

* Statistically significant at 0.05

As table (3) shows, there are statistically significant differences at level 0.05 between the pre and post tests of the experimental group in terms of technical performance of front crawl in favor of the pre test. 
Table (4)

Indication of the differences between the pre and post tests of the control group in terms of the level of technical performance in front crawl $N=20$

\begin{tabular}{|c|c|c|c|c|c|c|}
\hline \multirow{2}{*}{ Variances } & \multirow{2}{*}{$\begin{array}{c}\text { Unit of } \\
\text { measurement }\end{array}$} & \multicolumn{2}{|c|}{ Pretest } & \multicolumn{2}{|c|}{ Posttest } & \multirow{2}{*}{$\begin{array}{c}\mathbf{T} \\
\text { value }\end{array}$} \\
\hline & & independent & dependent & independent & dependent & \\
\hline Leg kicks & Degree & 4.00 & 1.71 & 7.60 & 1.29 & $7.72 *$ \\
\hline $\begin{array}{l}\text { Arm } \\
\text { movement }\end{array}$ & Degree & 2.90 & 1.33 & 7.24 & 1.02 & $9.34 *$ \\
\hline Breathing & Degree & 2.50 & 1.21 & 7.00 & 0.98 & $10.16^{*}$ \\
\hline $\begin{array}{l}\text { Overall co- } \\
\text { ordination }\end{array}$ & Degree & 2.34 & 1.25 & 6.80 & 0.93 & $9.98 *$ \\
\hline $\begin{array}{l}\text { Level of } \\
\text { front crawl }\end{array}$ & Degree & 11.74 & 4.16 & 28.64 & 2.61 & $15.11 *$ \\
\hline
\end{tabular}

$T$ value is at $0.05=2.093$ significance level

* Statistically significant at 0.05

As table (4) shows, there are statistically significant differences at level 0.05 between the pretests and

Table (5)

posttests of the control group in terms of technical performance of front crawl in favor of the posttest.

Indication of the differences between the posttests of the experimental and the control groups in terms of technical performance in front crawl

\begin{tabular}{l|l|l|l|l|l|l}
\hline \hline \multirow{2}{*}{ Variables } & \multirow{2}{*}{$\begin{array}{c}\text { Unit of } \\
\text { Measurement }\end{array}$} & \multicolumn{2}{|c|}{$\begin{array}{c}\text { The experimental group } \\
\text { N=20 }\end{array}$} & \multicolumn{2}{c|}{$\begin{array}{c}\text { The control group } \\
\text { N=20 }\end{array}$} & \multirow{2}{*}{$\begin{array}{c}T \\
\text { value }\end{array}$} \\
\cline { 3 - 7 } & & Independent & Dependent & Independent & Dependent & \\
\hline \hline Leg kicks & Degree & 8.78 & 1.14 & 7.60 & 1.29 & $2.99^{*}$ \\
\hline $\begin{array}{l}\text { Arm } \\
\text { movement }\end{array}$ & Degree & 8.40 & 0.97 & 7.24 & 1.02 & $3.59^{*}$ \\
\hline Breathing & Degree & 8.00 & 0.91 & 7.00 & 0.98 & $3.26^{*}$ \\
\hline $\begin{array}{l}\text { Overall } \\
\text { co- } \\
\text { ordination }\end{array}$ & Degree & 7.72 & 0.83 & 6.80 & 0.93 & $3.22^{*}$ \\
\hline $\begin{array}{l}\text { Level of } \\
\text { front } \\
\text { crawl }\end{array}$ & Degree & 32.90 & 2.47 & 28.64 & 2.61 & $5.17^{*}$ \\
\hline \hline
\end{tabular}

T value is at $0.05=2.042$ significance level

* Statistically significant at 0.05

Assiut Journal For Sport Science Arts 
As table (5) shows, there are statistically significant differences at level 0.05 between the posttests of the experimental and the control group in terms of technical performance in front crawl in favor of the experimental group.

Table (6)

Rates of improvement of the posttest compared to the pre test of the experimental and control groups in terms of technical performance in front crawl

\begin{tabular}{|c|c|c|c|c|c|c|}
\hline \multirow[b]{2}{*}{ Variables } & \multicolumn{3}{|c|}{ The experimental group $\mathrm{N}=20$} & \multicolumn{3}{|c|}{ The control group $\mathbf{N}=20$} \\
\hline & Pretest & Posttest & $\begin{array}{l}\text { Rates of } \\
\text { improvement }\end{array}$ & Pretest & Posttest & $\begin{array}{l}\text { Rates of } \\
\text { improvement }\end{array}$ \\
\hline $\begin{array}{l}\text { Front crawl } \\
\text { performance: } \\
\text { Leg kicks }\end{array}$ & 3.90 & 8.78 & $125.13 \%$ & 4.00 & 7.60 & $90.00 \%$ \\
\hline $\begin{array}{l}\text { Arm } \\
\text { movement }\end{array}$ & 2.84 & 8.40 & $195.77 \%$ & 2.90 & 7.24 & $149.66 \%$ \\
\hline Breathing & 2.40 & 8.00 & $233.33 \%$ & 2.50 & 7.00 & $180.00 \%$ \\
\hline $\begin{array}{l}\text { Overall co- } \\
\text { ordination }\end{array}$ & 2.26 & 7.72 & $241.59 \%$ & 2.34 & 6.80 & $190.60 \%$ \\
\hline $\begin{array}{l}\text { Level of } \\
\text { front crawl }\end{array}$ & 11.40 & 32.90 & $188.60 \%$ & 11.74 & 28.64 & $143.95 \%$ \\
\hline
\end{tabular}

As table (6) shows there are rates of improvement in the post test compared to the pre test of the experimental and control groups in terms of the level of technical performance in front crawl in favor of the experimental group.

\section{Discussion of results:}

A- Discussion of the results of the first hypothesis of the research:

The results of table (3) show that there are statistically significant differences at level 0.05 hetween the pre and post Assiut Journal For Sport Science Arts tests of the experimental group in terms of the level of technical performance in front crawl in favor of the post test. The researcher attributes the improvement of the level of technical performance of front crawl among the subjects of the experimental group to the effectiveness of using specific strength trainings-supported educational therapy style which was carefully designed in a structured manner according to some biomechanical indicators of 
some swimmers, and that led to the promotion of leg kicks, arm movement, breathing process and overall co-ordination. This has also efficiently contributed to the treatment of learning disabilities in front crawl.

This result is consistent with the study of: Moeen Ahmed Abdullah (2006), Jacob (2009), Mohammed FekrySayed Ahmed (2009), Ahmed ElSayed El-Habashy (2013) on the effectiveness of educational programs which are designed to treat learning disabilities in the promotion of skills performance in individual and team sports.

This result is also consistent with the studies of: Xiao-g (2000), Ashraf

MosaadAbdulhameed (2001), RandaShawkyHamza (2002), Mohammed Mahmud ElSagheer (2007), Noura Mohammed

SaeedAbdelmoneim (2010) on the importance of using specific strength trainings in the promotion of the level of skills performance for athletics. Riham Ahmed Fadel (2013) has added that while teaching front crawl to students, specific strength trainings should be used in order to treat some technical mistakes in leg kicks, arm movement, breathing process and overall coordinationimmediately after their emergence by carefully choosing a specific strength training for each technical mistake, so that the students' level of technical performance in swimming could be improved.

Thus, the validity of the first hypothesis has been established

B- Discussion of the research's second hypothesis:

As the results of table (4) show, there are statistically significant differences at level 0.05 between the pre and post tests of the control group in terms of the level of technical performance of front crawl in favor of the post test.

The researcher attributes the improvement of the level of technical performance in front crawl among the subjects of the control group to the use of the traditional method (verbal explanation and model performance) in the educational process. This 
method is characterized by the fact that, in this style, it'sthe teacher who takes all decisions related to the teaching style, and the role of the student becomes to perform in accordance with the model being presented by the teacher. Furthermore, students were used during their different educational stages to receiving information from the teacher without conducting researches. They were also used to learning skills from the teacher who does everything, while the student remains in a passive position (where she can only receive information) without exerting any efforts to learn andjust tries to imitate what the teacher,or the other learner who masters the skill,is doing in front of her.

Thus, the validity of the second hypothesis has been established

C- Discussion of the results of the research's third hypothesis:

As the results of table (5) show, there are statistically significant differences at level 0.05 between both post tests of the experimental and the control groups in terms of the level of technical performance of front crawl in favor of the experimental group.

Also, as the result of table (6) show, the subjects of the experimental group have surpassed those of the control group in terms of the improvement of the pre tests compared to the post tests of the level of technical performance in front crawl.

The researcher attributes such improvement to the effectiveness of using specific strength trainings-based educational therapy in the treatment of front crawl learning disabilities among the individuals of the experimental group. This has helped in providingthebody with the form and positions of proper performance and saving time and effort required for learning front crawl. While command teaching style based on verbal explanation and practical model, which had been followed with the subjects of the control group, does not take into account the individual differences between the learners, and thus provokes 
boredom. This led to the superiority of the subjects of the experimental group to those of the control group in terms of front crawl technical performance.

This result is consistent with Talha Hussein HossamEddin (1994) who has referred to the importance of using specific strength trainings and that such trainings shall be handled with great care given that they constitute the key for learning and mastering all sports skills in various games.

This result is also consistent with the following studies: Moeen Ahmed Abdullah (2006), Jacob (2009), Mohammed FekrySayed Ahmed (2009), Ahmed ElSayed El-Habashy (2013) on the effectiveness of using teaching styles-supported educational therapy in learning and mastering the motor skills for beginners with learning disabilities compared to the traditional method.

Thus, the validity of the research's third hypothesis has been established.

\section{Findings:}

Based on the presentation, discussion and interpretation of the results, the researcher was able to conclude the following:

1- The effectiveness of specific strength trainingssupported educational therapy in the promotion of the level of technical performance of front crawl for students with learning disabilities.

2- The traditional method (command teaching) has a positive effect on the level of technical performance in front crawl for students with learning disabilities.

3- The superiority of the subjects of the experimental group (specific strength trainings-supported educational therapy) on those of the control group (command teaching style) in terms of post tests and rates of improvement of post tests compared to the pre tests of the level of technical performance in frontcrawl among students with learning disabilities.

\section{Recommendations:}

In light of the obtained findings, the researcher recommends the following:

1- The necessity of using specific strength trainingssupported educational therapy 
in order to master front crawl for students with learning disabilities.

2- The necessity of using the specific strength trainings in question when teaching and training the students of the Faculty of Physical Education on front crawl.

3- Specific strength trainings shall follow the direction, form and details of front crawl rather than concentrating on the only physical aspect especially when it comes to teaching the skills.

4- Taking into account the individual differences between students with learning disabilities when using a specific teaching style seen that generalizing a specific style could be more convenient for a certain student but not for the other.

5- Using atypical teaching styles when teaching the practical aspect of swimming curriculum at the Faculties of Physical Education.

Bibliography

First: Arabic references: 1- Abu El-Ela Ahmed Abdulfattah

(1994):

Swimming Training for
Advanced Level, Dar El-Fikr Al-Araby, Cairo,

2- Ahmed El-Sayed ElHabashy (2013): The Effect of Using Educational Therapy on the Learning of Swimming among Students with Learning Disabilities, Master Thesis, Faculty of Physical Education, Benha University.

3- Ahmed ZakySaleh (1989): Imagery Intelligence and Exam Instructions Book, El-Nahda El-Arabya Library, Cairo.

4- Ahmed Ouda (2012): Measurement and Assessment in the Educational Process, $4^{\text {th }}$ ed., Dar El-Amal for Publishing and Distribution, Irbid, Jordan.

5- Ashraf

Mosed

Abdulhamid (2001): The Effect of Specific strength trainings on the Learning Some Basic Gymnastics Skills for Deaf and Dumb Students at the Primary Stage, Master Thesis, Faculty of Physical Education for Boys, Zagazig University.

6- El-Sayed Abdul-Hamid Soliman (2005): Learning Disabilities - History Concept - Diagnosis Treatment, $2^{\text {nd }}$ ed., Dar El-Fikr El-Araby, Cairo. 
7- RandaShawkyHamza

(2002): "The Effect of Using Specific strength trainings on the Level of Performance of the Skills of Pushing and Throwing the Ball In Field Hockey", PhD Thesis, Faculty of Physical Education for Girls, Zagazig University.

8- Riham Ahmed Fadel (2013): "Directing Some Biomechanical

Indicatorstowards the Improvement of the Phase of Maximum Speed for $50 \mathrm{~m}$ Freestyle Swimmers", $\mathrm{PhD}$ Thesis, Faculty of Physical Education for Girls, Zagazig University.

9- Tareq Mohammed

Nada (2004): Swimming Sport

- Educational and Practical Opinions, the Arab Center for Publishing, Zagazig.

10- Talha Hussein Houssam Eddin (1994): Functional Motor Basis for Sports Trainings, Dar El-Fikr El-Araby, Cairo.

11- Tahla Hossam Eddin, Wafaa Salah Eddin, Saeed Abdulrasheed (1997): the Scientific Encyclopedia of Sports Training, $1^{\text {st }}$ part, ElKitab Publishing Center, Cairo.
12- IssamEddin AbdelKhalek (2003): Sports Training - Theories and Applications, $4^{\text {th }}$ ed., Monshaat El-Maaref, Alexandria.

\section{3- Affaf Abdel-Karim} (1994): Teaching for Learning in Physical Education, Styles StrategiesAssessment, Monshaat El-Maaref, Alexandria. 14- Kamal

Zaytoun (2010): Teaching People with Special Needs, $2^{\text {nd }}$ ed., Dar ElFikr El-Araby, Cairo.

\section{5- Kamal Abdul-Hamid} Ismael, Mohammed Nasr Eddin Radwan (2005): Introduction to Physical Education, $2^{\text {nd }}$ edition, Dar ElFikr El-Araby, Cairo,

\section{6- Mohammed}

FekrySayed Ahmed (2009): "the Effect of Conductive Individualized Education Using Programmed Bookletfor the Treatment of Learning Disabilities in Drop Kick in Handball", Sports Sciences and Arts Magazine, Vol. (33), Faculty of Physical Sciences for Girls, Helwan University.

17- Mohammed Ali ElQuitt (2002): Educational Basis for Swimming, El-Azizy Library of Computer, Zagazig. 
18- Mohammed Ali ElQuitt (2005): Swimming Between Methodology and Application, El-Dowa for Printing and Publishing, Zagazig.

19- Mohammed Mahmud El-Soghayer (2007): The Effectiveness of Specific strength trainings Using Feedback Information on the Level of Front Flip Skill with Hands on Vault, Master Thesis, Faculty of Physical Education for Boys, Zagazig University. 20- Mustafa Kademet., al. (2000): Teaching Swimming Sport - Instruction, $2^{\text {nd }}$ ed., Dar El-Fikr El-Araby, Cairo.

21- Moeen

Abdullah (2006): "The Efficiency of the Teachers' Use of Educational Therapy for Students with Learning Disabilities in Physical Education", PhD Thesis, Faculty of Physical Education for Boys, Helwan University.

22- Noura Mohammed Saeed (2010): "The Effect of Using Specific strength trainings on the Improvement of the Quantitative Level of High Jumpin Physical Education Lesson", Master
Thesis, Faculty of Physical Education for Girls, Zagazig University.

23- Wafeeka Salem (2000):

Water Sports, Objectives, Teaching Methods, Teaching Basis, Assessment Basis, Monshaat El-Maaref, Alexandria.

Second: Foreign references:

24- Alfred, B., (2007): Problems the Commands Stylesin Physical Education, Journal Educational Research, Vol., 114 No., 40.

25- Batzer, A., (2005): The effect of Remedial of education programs on academic achievement and persistence at two-year community college., (ERIC Doc. ED 433867).

26- Coplin, J., \& Morgan, S. (1998): "Learning Disabilities:

Multidimensional Perspective". Journal of Learning Disabilities, Vol, 21, No., 10, P., 614-622.

27- Davison, G. \& Neale, J., (2007): "Abnormal Psychology: An Experimental Clinical Approach", 3 Rd.ed., New York, John Wiley \& Sons, Inc. 
28- Hammill, D., (1995):

"Exceptional

Children:

Introduction to Special Education" $4^{\text {th }}$ Ed. London, Printice-Hall International Inc. 29- Jacob, A., lefgren, 1., (2009): Remedial of education and student, Journal of research in Science Teaching, 39, (3), P.,891-904.

30- Kirik,H.,

(2003):

"Subtypes of Students with Learning Disabilities as Derived from Cognitive, Academic, Behavioral and Self Concept Measures", Learning Disability Quarterly, Vol., 13, No., 3, P., 183-194.

31- Kristy Rowland (1988): Boy Gymnastics rules Brice darbin Publisher, Ranssas, Missouri, U.S.A.
32- Lerner, J., (2010): Learning Disabilities, Theories, Diagnosis and Teaching Strategies, (8t ed.) Houghton Mifflin company, Bostonn., New York.

33- Shults, C., (2007): Remedial education: Practices and policies in community Colleges., (ERIC Doc., ED 448811).

34- Xiao,-G., (2000): Research on the specific strength training of gymnastics on the Chinese, sprail, Journal of Bejing University of physical education.

Third: "Internet" sites

35. http://www.Sahaara.com /Vb/Showthread.Php=2732336. http://www.Tesreen.com/daily/ 2002 aprmool/So.htm 